life, $a_{x: y}=a_{y}$ (both of them being zero), and the age of the younger life has no effect whatever on the value. Accordingly, the substituted age $w$ must be nearer the older than the younger of the two lives, or $w>(x+y): 2$ and the excess increases with the difference between $x$ and $y$. On the other hand the last survivor annuity may continue for the "eomplement of life" of the younger of the two lives, however old the other may be; and the age of the younger is therefore the preponderating factor in this case, and the preponderance increases with the difference between $x$ and $y$ until, in the limit, when $y$ reaches the limit of life, $a_{x: y}=a_{x}$, and the value depends solely on the age of the younger life. Therefore the age $z$ at which $a_{x \overline{x: y}}=a_{\overline{z: z}}$ must be nearer the younger than the older life, or $z<(x+y): 2$. Hence $z$ must be less than $w$, and accordingly $a_{\bar{\omega}, 4}$ greater than $a_{w: w}$, and the difference between them increases with the difference between $x$ and $y$.

Yours faithfully,

A. E. SPRAGUE.

Edinburgh 26 August, 1910.

\title{
RELATION BETWEEN RATES OF SICKNESS AND SIZE OF LODGE.
}

To the Editor of the Journal of the Institute of Actuaries.

SIR,-One of the most striking features of the monumental work of Mr. Alfred W. Watson, as shown in his paper in J.I. A., xxxv, is the apparent proof that the rates of sickness increase with the size of the lodge, vide the tables shown on pages 289 et seq., and the accompanying remarks. I reproduce Table 16 (p. 291).

TABLE 16.

\begin{tabular}{|c|c|c|c|c|c|c|c|c|}
\hline \multirow{3}{*}{$\begin{array}{l}\text { Number of } \\
\text { Members } \\
\text { in the } \\
\text { Lodge }\end{array}$} & \multirow{3}{*}{$\begin{array}{l}\text { Total } \\
\text { No. of } \\
\text { Lodges } \\
\text { in the } \\
\text { gloup }\end{array}$} & \multirow{3}{*}{$\begin{array}{c}\text { Pereet tage } \\
\text { of the } \\
\text { whole } \\
\text { number of } \\
\text { Lodges }\end{array}$} & \multicolumn{6}{|c|}{ SICKNess Cost } \\
\hline & & & \multicolumn{2}{|c|}{ HIGH } & \multicolumn{2}{|c|}{ NoraiaI } & \multicolumn{2}{|c|}{ Low } \\
\hline & & & $\begin{array}{l}\text { No. of } \\
\text { Lodges }\end{array}$ & $\begin{array}{l}\text { Percentage } \\
\text { of the } \\
\text { number of } \\
\text { Lodges in } \\
\text { the gronp }\end{array}$ & $\begin{array}{l}\text { No. of } \\
\text { Lodges }\end{array}$ & $\begin{array}{l}\text { Pereentage } \\
\text { of the } \\
\text { number of } \\
\text { Lodges in } \\
\text { the group }\end{array}$ & $\begin{array}{l}\text { No. of } \\
\text { Lodges }\end{array}$ & $\begin{array}{l}\text { Percentage } \\
\text { of the } \\
\text { number of } \\
\text { Lodges in } \\
\text { the group }\end{array}$ \\
\hline Under 80 & 823 & 23 & 337 & $\begin{array}{c}\text { Per cent. } \\
41\end{array}$ & 255 & $\begin{array}{l}\text { Per cent. } \\
31\end{array}$ & 231 & $\begin{array}{c}\text { Per cent } \\
28\end{array}$ \\
\hline $80-149$ & 1,059 & 30 & 543 & 51 & 314 & 30 & 202 & 19 \\
\hline $150-249$ & 877 & 24 & 504 & 57 & 212 & 24 & 161 & 19 \\
\hline $250-3+9$ & 425 & 12 & 278 & 66 & 87 & 20 & 60 & 14 \\
\hline $350-489$ & 279 & 8 & 206 & 74 & 47 & 17 & 26 & 9 \\
\hline $\begin{array}{c}500 \text { and } \\
\text { over }\end{array}$ & 118 & 3 & 97 & 82 & 11 & 9 & 10 & 9 \\
\hline$\cdots$ & 3,581 & 100 & 1,965 & 55 & 926 & 26 & 690 & 19 \\
\hline
\end{tabular}


Table 17 given by Mr. Watson shows that the results in Table 16 are singularly confirmed when investigated under eight headings according to occupation, with the sole exception of the Textile in respect of whom he says "It is true that amongst the Textile classes there is no appreciable increase of claims with enlargement of the membership, but these classes are otherwise quite exceptional in showing, amongst occupations, the lowest percentage of cases of sickness excess." Table 15 shows that in the Textiles as a whole 41 per-cent of the lodges had a normal experience, 28 per-cent a high cost, and 31 per-cent a low cost.

This question is one of considerable practical importance at any rate on this side of the globe. Thongh Mr. Watson's figures and conclusions have stood unchallenged for over 10 years yet I venture to suggest that, striking and consistent as the results appear to be, the figures are open to eriticism.

The form in which the figures are given is that of a record of the proportionate deviation from the 1866-1870 standard. For instance, of the 823 lodges of less membership than 80 , it is shown that 31 percent have a "normal" experience, while 41 per-cent deviate in a positive direction and 31 per-cent a negative direction (normal being somewhat vaguely defined as "in approximate agreement" meaning presumably within fixed percentage limits).

Mathematical analysis shows us that other things being equal there should be a proportionately smaller deviation in large than in small lodges, the probable deviation being a function of the square root of the membership. If a number of lodges of all sizes were grouped according to size, the groups being subject to sickness rates conforming to a common standard, we should therefore expect to find a comparatively greater proportion of the lodges in the large groups with an experience falling within a given percentage of the common standard.

The truth of this is evident from consideration of the manner in which positive and negative deviations tend to fall together and counterbalance one another as lodges are thrown together to form larger bodies, and it is almost obvious from rhetorical reasoning that as the process of such hypothetical amalgamation proceeds, the curve (of frequency) set up to display their grouping about, or proportionate deviation from, the common standard, will tend to swell in the middle (representing the increasing proportion of lodges with an experience within fixed limits of deviation), until the curve gradually approaches the bell shaped stage, passing later on to the Eiffel Tower stage, and eventually with a group of extremely large lodges, approximating to a single upright straight line.

Consider now the case where a perpendicular is drawn at a given distance from the centre to represent a new centre, say, for instance, we simply adopt as a new centre the ordinate representing a deviation of 10 per-cent. It is quite evident that the flatter and wider spread curves of the small lodges would not be so lopsided about this new centre as would the bell shaped or Eiffel Tower curves of the larger lodges. The group of infinitely large lodges 
whose curve was a single straight line would in fact depart entirely from the centre. The larger the lodges therefore the more would their curves tend to depart from the new centre.

To take an example if it were found that one-tenth of the small lodges had an experience falling within 5 per-cent of the supposed common standard it might be expected that say one-third of the lodges of a certain larger size would come within the same percentage limit. If we compare these lodges with a new standard giving rates of sickness 10 per-cent lower it follows that all the above cases would rank as over 5 per-cent in excess, thus shifting one-third of the larger lodges into the excess group as against only one-tenth of the smaller ones. Thus such a comparison would give lopsided results even where each group of lodges was really subject to the same experience.

The comparison made with the 1866-1870 standard is open to this very objection as the standard exhibits lower rates than the actual experience of the lodges; and it seems probable that if the lodges had been compared with a standard higher than their own experience the apparent showing of the figures would have been in a diametrically opposite direction.

The Textile group had an experience agreeing more closely with the 1866-1870 standard and their results which before appeared exceptional would now appear to be quite consistent, tending in fact to exemplify the above contention.

There may of course be other facts tending to show that the sickness rates increase with the size of the lodge, and it would be interesting to know how the large and small lodges compare in respect of amounts of sickness (though even in this case a comparison with the 1866-1870 standard would tend to militate against the groups having the greatest proportion of old lodges or old members). It may be added that figures taken out for about two-thirds of the New Zealand membership do not confirm the idea.

Yours truly,

A. T. TRAVERSI.

Wellington, Neno Zealand, 15 October 1910.

[Mr. A. W. WATsoN, to whom the above letter was communicated at Mr. Traversi's suggestion, sends us the following remarks for publication.-ED. J.I.A.].

Mr. Traversi suggests an interesting, and in certain circumstances, valid alternative interpretation of Table 16 to that put forward in my paper. But further and more complete experience, collected since I wrote in 1899, confirms the inference which I drew from Table 16, namely, that the size of a friendly society and the consequent relative facility of effective supervision is a factor in the sickness claims. On this point $I$ need only quote the following figures from the paper which I had the honour to submit to the Institute in January 1910 (J.I.A., vol. xliv, p. 220). 


\begin{tabular}{|c|c|c|}
\hline \multirow{2}{*}{ Number of Members } & \multicolumn{2}{|c|}{$\begin{array}{c}\text { Peroentage of Siekness Costs } \\
\text { To EXPECTaTION BashD ON } \\
\text { 1866-70 StaNoARD }\end{array}$} \\
\hline & Rural & Urban \\
\hline $\begin{aligned} \text { Under } & 150 \\
& 150-249 \\
& 250 \text { and over }\end{aligned}$ & $\begin{array}{r}97 \\
103 \\
106\end{array}$ & $\begin{array}{l}104 \\
108 \\
110\end{array}$ \\
\hline
\end{tabular}

The use of the 1866-70 experience as the basis of this last comparison appears to me to be quite free from the objection which Mr. Traversi urges with regard to the earlier compilation. Some time must elapse before materials are available for a comparison based upon the 1893-7 Standard, but the Table which I give on p. 227 of vol. xliv. of the Journal refers approximately to this basis, the general average of 106 per-cent of the 1866-70 expectations having been adopted as the Standard (100 per-cent) and the figures of the preceding Tables adjusted accordingly.

The proportionate distribution of the facts about the mean of each group is readily deducible from this Table and generally will be found, on trial, to be different in marked degree from a distribution according to the normal curve of error. This is probably due to disturbing causes which could only be removed by breaking up the data into further sub-groups, a process which is hardly justified by the extent of the facts available. Whilst the "spread" of the facts is least in the groups referring to the larger lodges (this is perhaps better seen by the Table on page 225), thus in a measure confirming the theoretical law of distribution enunciated by Mr. Traversi, each group has a mean distinct from that of the other groups, and corresponding with the general averages quoted in full above, allowance being made, of course, for the change of basis.

It is interesting to learn on the competent authority of $\mathrm{Mr}$. Traversi that the experience of the New Zealand Societies does not exhibit this feature. Probably the general rate of sickness-claim in New Zealand is lower than in the mother country, a condition which I have found to be widely prevalent amongst the societies of South Africa and South Australia. Causes for this phenomenon will readily suggest themselves. If malingering be rare, it follows that the statistical symptoms of malingering must be faint. I trust that this is the solution of the negative New Zealand experience.

Having regard to the reservation in Mr. Traversi's last paragraph I deem it necessary to add that old and young lodges are well mixed in all my groups. Before putting them forward I satisfied myself that the figures were quite without bias under this particular head.

A. W. W.

5 December 1910. 